\title{
Basic Income, Gender and Human Rights
}

\author{
Beth Goldblatt*
}

\begin{abstract}
Basic income has been a prominent policy proposal from a range of quarters in the context of uncertainty over the future of work and the problem of growing economic inequality. More recently it is being considered in some countries as a possible response to the economic fallout of the COVID-19 pandemic. A basic income is an unconditional, tax-financed, government payment provided to every member of society. It has recently been articulated by the UN Special Rapporteur on extreme poverty and human rights, Philip Alston, as a human rights issue. It has also been the subject of long-standing debate amongst feminists about its likely benefit for women and gender equality. This article explores the intersections between basic income, gender and human rights. It provides some background to the discussion of a basic income within human rights and within feminism before considering how a human rights lens informed by gender might deepen the debate on basic income and contribute to the development of social policies that address gendered poverty and inequality. It also gives some thought to the value of a human rights framing of basic income for the feminist project.
\end{abstract}

Keywords: Basic income, gender, feminism, human rights

\section{Introduction}

The idea of a basic income, 'paid by a political community to all its members on an individual basis, without means test or work requirement', '

\footnotetext{
* Professor, Faculty of Law, University of Technology Sydney; Visiting Professor, School of Law, University of the Witwatersrand. Sincere thanks to the anonymous reviewers and journal editors for very helpful feedback on earlier versions of this article.

' Philippe Van Parijs, 'Basic Income: A Simple and Powerful Idea for the Twenty-First Century' (2004) 32 Politics and Society 7, 8.
} 
is a fiercely debated policy option. The idea has a long history and has generated a rich academic literature covering basic income's philosophical premises, feasibility and likely impact. ${ }^{2}$ There is also a prominent movement across the world on basic income with many vocal supporters. The idea is being floated at the highest levels and in a wide range of forums. In 2018, the UN Secretary General in a speech to the General Assembly said governments may need to consider a basic income in responding to the changing nature of work as a result of technological innovation. Former US president Barack Obama in his 2019 Nelson Mandela lecture also called for discussion of a basic income in response to technological change, globalisation, challenges to work, and even the problems facing democracies. ${ }^{5}$ At a time of global uncertainty a basic income is being proposed by diverse voices across the political spectrum, including technology and business leaders such as Mark Zuckerberg, Elon Musk and Richard Branson. ${ }^{6}$

The COVID-19 pandemic lockdowns and their severe consequences for economies, employment and livelihoods have turned the basic income debate into a live policy issue in some countries. The economic downturn, described as a 'pink collar recession', is having a particularly harsh impact on women. 'This is because women are in industries and roles hardest hit by job cuts, loss of access to child care, and because women were already the most precarious workers. Lack of state support due to a decade of austerity cuts in many countries following the 2008 financial crisis have left

\footnotetext{
2 There is an entire journal devoted to it. See Basic Income Studies, <https://www.degruyter.com/view/j/bis?lang=en> accessed 1 September 2020, and large numbers of books and edited collections; some prominent recent examples: Karl Widerquist and others (eds) Basic Income: An Anthology of Contemporary Research (Wiley-Blackwell 2013); Guy Standing, Basic Income: And How We Can Make It Happen (Penguin Random House 2017); Malcolm Torry (ed), The Palgrave International Handbook of Basic Income (Palgrave Macmillan 2019); Philippe Van Parijs and Yannick Vanderborght, Basic Income: A Radical Proposal for a Free Society and a Sane Economy (Harvard University Press 2017); Rutger Bregman, Utopia for Realists: And How We Can Get There (Bloomsbury 2018).

${ }^{3}$ An international network founded in 1986, the Basic Income Earth Network (BIEN) holds regular international conferences.

4 António Guterres, 'Address to the General Assembly' (2018) <https://www.un.org/sg/en/content/sg/speeches/2018-09-25/address-73rd-general-assembly> accessed 1 September 2020.

Barack Obama, 'Nelson Mandela Annual Lecture 2018' (2018) <https://www.nelsonmandela.org/news/entry/nelson-mandela-annual-lecture-2018-obamasfull-speech> accessed 1 September 2020.

${ }^{6}$ Catherine Clifford, 'What Billionaires and Business Titans Say About Cash Handouts in 2017 (Hint: Lots!)' (CNBC, 28 December 2017) <https:/www.cnbc.com/2017/12/27/whatbillionaires-say-about-universal-basic-income-in-2017.html> accessed 1 September 2020.

Nancy Wang, 'COVID Leads to a Pink Collar Recession' (Forbes, 24 May 2020) <https://www.forbes.com/sites/nancywang/2020/05/24/covid-leads-to-a-pink-collarrecession/\#7d41553e2bb5> accessed 1 September 2020.
} 
vulnerable workers and carers with little to fall back on. As the UN Secretary-General has noted:

Across the globe, women earn less, save less, hold less
secure jobs, are more likely to be employed in the
informal sector. They have less access to social protections
and are the majority of single-parent households. Their
capacity to absorb economic shocks is therefore less than
that of men.

In June 2020, Spain introduced a monthly cash payment heralded as a basic income. ${ }^{9}$ The new program is not universal since it is means tested and paid to the poorest households only - it is thus a guaranteed minimum income rather than a universal basic income. Spain alongside Portugal and Italy are proposing a common approach to minimum income within the EU. ${ }^{10}$ A UN Development Program report has proposed what it terms a 'temporary basic income' for developing countries which are emergency unconditional cash transfers to address the most vulnerable during the pandemic." South Africa has flagged something along these lines. In July 2020, the Social Development Minister spoke of government introducing a Basic Income Grant to support people aged 18-59, the group currently left out of social assistance provided for children, the aged and people with disabilities. ${ }^{12}$ This too would effectively be a minimum income for a large group of the poor rather than a fully-fledged basic income, and would ideally last beyond the pandemic as it fills a need that had long been there. It seems that in some countries the crisis has led to an acknowledgement of large gaps in social protection and the market's incapacity to provide adequate employment opportunities. These initiatives add impetus to the

\footnotetext{
${ }^{8}$ 'UN Secretary-General, 'Policy Brief: The Impact of COVID-19 on Women' (2020) <https://www.unwomen.org/en/digital-library/publications/2020/04/policy-brief-the-impactof-covid-19-on-women> accessed 1 September 2020.

${ }^{9}$ Carrie Arnold, 'Pandemic Speeds Largest Test Yet of Universal Basic Income' (2020) 583Nature 502-03.

${ }^{10}$ Ashifa Kassam, 'Spain Rekindles a Radical Idea: A Europe-Wide Minimum Income' The Guardian (London, 3 June 2020 ) <https://www.theguardian.com/world/2020/jun/03/spain-rekindles-a-radical-idea-a-europewide-minimum-income> accessed 1 September 2020.

${ }^{11}$ George Gray Molina and Eduardo Ortiz-Juarez Temporary Basic Income: Protecting Poor and Vulnerable People in Developing Countries (UNDP 2020).

${ }^{12}$ Sandisiwe Shoba, 'Basic Income Grant on the Table for South Africa's Unemployed Poor', The Daily Maverick, (Johannesburg, 14 July 2020, <https://www.dailymaverick.co.za/article/2020-07-14-basic-income-grant-on-the-table-forsouth-africasunemployedpoor/Pfbclid=IwAR3O2EQZwbgz3vejGHly8W8b7VOJ6bwt0UAqJIgm9H5fAauVhgK5IL.9zVY> 1 September 2020 .
} 
pre-pandemic interest in a basic income. A positive example of efforts to combine the call for a basic income with a focus on the gendered impacts of the crisis comes from Hawaii's Commission on the Status of Women which has proposed a 'feminist economic recovery plan' in response to the damage wrought by COVID-19. The plan includes a basic income alongside wages for family/informal carers and free childcare for essential workers. ${ }^{13}$

Recently, basic income has been articulated as a human rights issue, notably by Professor Philip Alston in his capacity as then UN Special Rapporteur on extreme poverty and human rights. ${ }^{14}$ In his 2017 report to the UN Human Rights Council, he observed that there is a growing sense of economic insecurity to which the human rights system has done little to respond. ${ }^{15}$ He argued that discussion of a basic income provides an opportunity to explore the form of social protection that can best secure human rights at a global level. ${ }^{16}$

While basic income and international human rights had little intersection prior to this report, there has been even less consideration of women's rights and how they relate to considerations of gender equality within basic income debates. Alston's report noted that economic insecurity has negative implications for gender inequality and suggested that 'proponents of women's human rights need to become more involved in debates over social protection and basic income'. ${ }^{17}$ An International Labour Organization (ILO) report similarly suggested the need for 'a careful and comprehensive analysis of the various implications of a UBI (Universal Basic Income) for women's rights and their empowerment'. ${ }^{\text {18 }}$

This article responds to these suggestions by exploring the intersections between basic income, gender and human rights. Basic income has long been the subject of disagreement amongst feminists, some of whom see it advancing gender equality in the workforce and society while others are more sceptical or even fearful of its potential negative

\footnotetext{
${ }^{13}$ Hawai'i State Commission on the Status of Women, Building Bridges, Not Walking on Backs: A Feminist Economic Recovery Plan for COVID-19' (2020) <https:/humanservices.hawaii.gov/wp-content/uploads/2020/04/4.13.20-Final-Cover-D2Feminist-Economic-Recovery-D1.pdf> 1 September 2020.

${ }^{14}$ UN Special Rapporteur on extreme poverty and human rights, 'Universal Basic Income' (2017) A/HRC/35/26.

${ }^{1.5}$ ibid [5].

${ }^{16}$ ibid [60].

${ }^{17}$ ibid [72].

${ }^{18}$ Isabel Ortiz and others, 'Universal Basic Income proposals in Light of ILO Standards: Key Issues and Global Costing' (2018) ILO Working Paper No 62, 28 <https://www.ilo.org/secsoc/information-resources/publications-andtools/Workingpapers/WCMS_648602/lang--en/index.htm> accessed 1 September 2020.
} 
impact on women's lives. ${ }^{19}$ However these debates, occurring in fields such as politics and economics, have remained largely outside of the human rights law space. This article considers how a gender rights lens might deepen the debate about a basic income and contribute to the development of social policies that address gendered poverty and inequality.

A human rights approach that is attentive to gender suggests that a basic income is likely to assist women who are disproportionately poor and vulnerable in all societies. But on its own it will not address the complex and structural inequality that they face. A basic income will need to be accompanied by measures such as the provision of childcare and support for sole parents, alongside changes to the labour market and tax system. It will also have to be of adequate size to make a real difference to inequality. The form of a basic income, its likely impact and its desirability as a policy solution is contingent on the political and economic conditions of the particular country in which it is being considered and should be subject to democratic deliberation. Human rights principles informed by gender will help to ensure that any basic income proposal is carefully evaluated within the context of that country to advance rather than impede substantive gender equality.

The article begins with an outline of how human rights informed by gender can provide guidance on key questions of social protection, which inform the discussion of a basic income (Section 2). It then undertakes a brief examination of the concept of a basic income, the problems it seeks to address, and current attempts to test its viability (Section 3). It goes on to note recent consideration of basic income as a human rights issue (Section 4). The article then discusses the major strands within the feminist debates on a basic income within the context of gender inequality in the home, workplace and society more broadly (Section 5). Thereafter it demonstrates how a human rights approach informed by gender applies to a consideration of basic income (Section 6). Lastly, the article discusses the value of a human rights framing of basic income for the feminist project (Section 7).

\footnotetext{
${ }^{19}$ For overviews of this debate see Annie Miller, Toru Yamamori and Almaz Zelleke, 'The Gender Effects of a Basic Income' in Malcolm Torry (ed), The Palgrave International Handbook of Basic Income (Palgrave Macmillan 2019); Yannick Vanderborght and Karl Widerquist, 'The Feminist Response to Basic Income' in Karl Widerquist and others (eds) Basic Income: An Anthology of Contemporary Research (Wiley-Blackwell 2013); Alisa McKay, The Future of Social Security Policy: Women, Work and a Citizens' Basic Income (Routledge 2005).
} 


\section{A Human Rights Approach to Social Protection Informed by Gender}

Feminists have engaged with human rights to ensure that women's experiences and gender considerations are given appropriate attention. Some of this engagement concerns social and economic rights including rights to livelihood, social security, and work and its relationship to care (which I discuss together here as rights to social protection). Certain key ideas have emerged in providing a gender approach to social protection rights that are set out here to frame the discussion of a basic income. ${ }^{20}$ These ideas recognise that central principles within social protection rights including non-discrimination, adequacy, accessibility, and a life-cycle approach must be informed by an understanding of gender and the way that men and women's different experiences shape their social protection needs.

Key to ensuring this gendered human rights approach is the principle of equality and non-discrimination informed by the concept of substantive gender equality which requires far-reaching, structural and transformative responses. ${ }^{21}$ The UN Committee on Economic, Social and Cultural Rights in its General Comment No 19 on the right to social security has noted that non-discrimination and equality between men and women pervade all the obligations in the International Covenant on Economic, Social and Cultural Rights (ICESCR) ${ }^{22}$ which 'prohibits any discrimination, whether in law or in fact, whether direct or indirect' on a range of listed grounds including sex 'which has the intention or effect of nullifying or impairing the equal enjoyment or exercise of the right to social security'. ${ }^{23}$ The Committee has explained that it is not enough to simply remove formal

\footnotetext{
${ }^{20}$ See Beth Goldblatt and Lucie Lamarche (eds), Women's Rights to Social Security and Social Protection (Hart Publishing 2014); Magdalena Sepúlveda and Carly Nyst, The Human Rights Approach to Social Protection (Ministry for Foreign Affairs 2012); Beth Goldblatt, Developing the Right to Social Security: A Gender Perspective (Routledge 2016); Sandra Fredman, 'Engendering Social Welfare Rights' in Beth Goldblatt and Lucie Lamarche (eds), Women's Rights to Social Security and Social Protection (Hart Publishing 2014); Magdalena Sepúlveda Carmona, 'Ensuring Inclusion and Combatting Discrimination in Social Protection Programmes: The Role of Human Rights Standards' (2017) 70 International Social Security Review 13.

${ }^{21}$ Sandra Fredman, Discrimination Law $\left(2^{\text {nd }}\right.$ ed, Claredon 2011) explains that this equality is multi-dimensional in ensuring redistribution, recognition, participation and transformation. For its application to gender and human rights see Sandra Fredman and Beth Goldblatt, Gender Equality and Human Rights (2015) UN Women Discussion Paper No 4.

${ }^{22}$ (adopted 16 December 1966, entry into force 3 January 1976) 3 UNTS 999.

${ }^{23}$ Committee on Economic, Social and Cultural Rights (CESCR), 'General Comment No 19: The Right to Social Security' (2008) E/C.12/GC/19 [29].
} 
discrimination if substantive equality is to be achieved. ${ }^{24}$ In some instances special or positive measures will be needed to overcome persistent discrimination. ${ }^{25}$ The UN Committee on the Elimination of Discrimination Against Women has a broad conception of substantive equality that requires a systemic approach. It says that:

The position of women will not be improved as long as the underlying causes of discrimination against women, and of their inequality, are not effectively addressed. The lives of women and men must be considered in a contextual way, and measures adopted towards a real transformation of opportunities, institutions and systems so that they are no longer grounded in historically determined male paradigms of power and life patterns. ${ }^{26}$

A substantive gender equality approach is thus deeply contextual and attentive to historical and current differences in the experiences of men and women. It is multidimensional in requiring that inequality overcomes distributive disadvantage and status-based harms and must ensure participation of women in developing responses to inequality that are appropriate, as well as transformative, leading to structural challenges to patriarchal relations. ${ }^{27}$ In the context of social protection this requires particular attention to women's location in relation to paid and unpaid work and their responsibilities for providing care to a range of groups including children, the elderly, people with disabilities and illnesses, as well as also being members of these groups. ${ }^{28} \mathrm{~A}$ gender equality rights-based approach thus, in addition, requires measures to take account of intersectional disadvantage. Intersectionality, formulated in the context of US anti-discrimination law, ${ }^{29}$ is now well entrenched in international human rights law. ${ }^{30}$ Social protection based on human rights must take account of how various disadvantaged groups such as women with disabilities or women of colour are differently affected than other groups

\footnotetext{
${ }^{24}$ CESCR, 'General Comment No. 20: Non-Discrimination in Economic, Social and Cultural Rights' (2009) E/C.12/GC/20 [8].

${ }^{25}$ ibid [9].

${ }^{26}$ Committee on the Elimination of Discrimination Against Women, 'General Recommendation No. 25: Temporary Special Measures' (2004) CEDAW/C/GC/25 [10].

${ }^{27}$ Fredman, Discrimination Law (n 21).

${ }^{28}$ Goldblatt (n 20).

${ }^{29}$ Kimberlé Crenshaw, 'Demarginalizing the Intersection of Race and Sex: A Black Feminist Critique of Antidiscrimination Doctrine, Feminist Theory and Antiracist Politics' (1989) 1 University of Chicago Legal Forum 139.

${ }^{30}$ Beth Goldblatt, 'Intersectionality in International Anti-Discrimination Law: Addressing Poverty in its Complexity' (2015) 21 Australian Journal of Human Rights 47.
} 
of women and require policy responses that are designed to address these complex inequalities.

A feature of rights to social protection is that they must provide an adequate standard of living. Article 11(1) of ICESCR set out the rights as including:

... the right of everyone to an adequate standard of living for himself and his family, including adequate food, clothing and housing, and to the continuous improvement of living conditions.

Adequacy is an essential element of the right to social security. The Committee on Economic, Social and Cultural rights explained that:

Benefits, whether in cash or in kind, must be adequate in amount and duration in order that everyone may realize his or her rights to family protection and assistance, an adequate standard of living and adequate access to health care ... States parties must also pay full respect to the principle of human dignity contained in the preamble of the Covenant, and the principle of non-discrimination, so as to avoid any adverse effect on the levels of benefits and the form in which they are provided. ${ }^{31}$

Adequate social protection that is attentive to gender must ensure that income support takes account of the position of women within households, women's unpaid work and care obligations, women's lower earnings and savings, and women's position in the workforce which is often informal and precarious. What constitutes adequacy and whether there are minimum core levels of provision required by rights has been debated within the field of social and economic rights . ${ }^{32}$ In addition, valid concerns have been raised with a human rights emphasis on sufficiency leading to efforts to tackle poverty without also ensuring distributive equality. ${ }^{33} \mathrm{~A}$ substantive equality approach to social protection rights requires structural responses to systemic inequality via social, economic and political reconfigurations that lead to fundamental changes to gender, class and other relations. ${ }^{34}$ It thus requires policies aimed at overcoming inequality

\footnotetext{
${ }^{31}$ CESCR, 'General Comment No 19' (n 23) [22].

${ }^{32}$ Katharine G. Young, 'The Minimum Core of Economic and Social Rights: A Concept in Search of Content' (2008) 33 Yale Journal of International Law 113-75.

${ }^{33}$ Samuel Moyn, Not Enough: Human Rights in an Unequal World (HUP 2017).

${ }^{34}$ For a discussion of this approach to equality see Catherine Albertyn (2018) 'Contested Substantive Equality in the South African Constitution: Beyond Social Inclusion Towards
} 
rather than just providing minimum levels of poverty relief. This idea of adequacy should be central to the human rights lens used to consider questions of the theory, design and politics of a basic income. In addition, adequacy must be understood as a global issue since affordability and economic choices facing states require international cooperation and assistance, as required by the ICESCR. ${ }^{33}$

Social protection rights also need to ensure accessibility so that women are fully covered and able to access payments. This must include those women who are illiterate, physically remote, migrants and refugees. Since social protection is aimed at addressing different contingencies and needs across the life-course it should recognise that gender is critical to the constitution of these needs and should be central to the development of income benefits that address and overcome these needs. In addition, social protection must be formulated in light of the interdependence of all human rights ${ }^{36}$ so, for example, rights to health, housing, livelihood, and social services that are also profoundly gendered must be considered in taking a comprehensive approach to measures that will support people's full range of needs. Lastly, the presumption against non-retrogression requires states to show that they are not removing any entitlements to social rights without justification. ${ }^{37}$ This has significance for women who must be provided with opportunities for meaningful participation to ensure that their needs are considered before any existing social protection measures are removed when new policies, such as a basic income, are introduced.

Bearing in mind this human rights approach to social protection informed by gender, the article now considers how this could have bearing on the basic income debate.

\section{Basic Income-What? Why? And Attempts to Test It}

A basic income, also called a universal basic income (UBI), is an unconditional, tax-financed, government payment provided to every member of society. There are however a wide variety of formulations

Systemic Justice' (2018) 34(3) South African Journal on Human Rights 441; Gillian MacNaughton, 'Equality Rights Beyond Neoliberal Constraints' in Gillian MacNaughton and Diane Frey (eds) Economic and Social Rights in a Neoliberal World (CUP 2018).

${ }^{35}$ Articles 2(1) and 11(1) of ICESCR (n 22). Also see Goldblatt, Developing the Right to Social Security (n 20) at 36-9 for an application of Nancy Fraser's concept of 'scale' to the right to social security approached from a gender perspective.

${ }^{36}$ Vienna Declaration and Programme of Action (1993) A/CONF.157/23 [5].

${ }^{37}$ CESCR, 'General Comment No 19' (n 23) [42]. 


\section{"Basic Income"}

proposed by scholars and advocates that take different approaches to definitions of universality, conditionality, adequacy, and integration within the existing social protection system. ${ }^{38}$ It is seen as 'basic' in that it only covers sufficient resources to function in a given society. This may mean very different amounts in different societies based on the cost of living, availability of services and on relative standards of sufficiency, adequacy and definitions of 'functioning', but it is always directed towards ensuring a minimum level of economic security. ${ }^{39}$ Some proposals view a basic income as a "small "top-up" to other sources of income, as a partial income, or as a fully liveable income'. ${ }^{40}$ The expansive end of this spectrum might require adequacy and decency or dignity to be central to the meaning of 'basic'. "Considerations of what amount of income is possible, likely and ideal are key to deciding whether a proposal is worth supporting, and also relate to whether it may be capable of addressing systemic inequality through substantial redistribution.

The fact that on most models basic income is provided by the state to individuals within its boundaries raises some issues for the eligibility of non-citizens and residents of different statuses and again there are differing views on this. ${ }^{42}$ Some models propose a basic income for adults with a smaller grant for children. ${ }^{43} \mathrm{~A}$ strong argument for a basic income is that the absence of means testing and conditions such as work-seeking or being in employment reduces bureaucracy and saves administrative costs. This is quite a radical idea, particularly in the neo-liberal era where income support has become increasingly constrained under conditions of austerity and is often tied to meeting conditions to prove that the applicant is 'deserving'. The idea of a basic income raises challenging philosophical questions about how we understand our obligations to each other and view the social contract, including how we understand individual decisions about paid and unpaid work. One of the arguments for a basic income is that it expands individual freedom to pursue meaningful activities that are not income-generating or are lower paid. The idea also raises economic

\footnotetext{
${ }^{38}$ Margot Young and James Mulvale, Possibilities and Prospects: The Debate Over a Guaranteed Income (2009) Canadian Centre for Policy Alternatives <http://www.socialrightscura.ca/documents/publications/margot/CCPA_Guaranteed_Incom e.pdf $>$ accessed 1 September 2020 .

${ }^{39}$ Although the level it is set at is itself the subject of philosophical debate, economic conditions and strategic considerations see Standing (n 2) 4.

${ }^{40}$ Young and Mulvale (n 38) 18.

${ }^{41}$ ibid.

${ }^{42}$ Àlex Boso and Mihaela Vancea, 'Basic Income for Immigrants? The Pull Effect of Social Benefits on Migration' (2012) 7(1) Basic Income Studies 1; Ann-Helén Bay and Axel West Pedersen, 'The Limits of Social Solidarity: Basic Income, Immigration and the Legitimacy of the Universal Welfare State' (2006) 49 Acta Sociologica 419.

${ }^{43}$ Van Parijs and Vanderborght (n 2) 9.
} 
questions about levels of taxation, affordability, the retention or removal of existing income support and other social welfare schemes, and the likely impact of a basic income on the economy. Various proposals suggest a tax claw-back from the wealthy which also addresses concerns about the seeming unfairness of a payment provided to rich and poor alike. One of the sub-issues within the basic income debate relates to the potential environmental benefits. A basic income is seen as a means of slowing down the exponential and unsustainable model of economic growth that currently animates our capitalist system by allowing people to consume less and work in ways that use less resources."

In addition to issues of sustainability, the recent interest in a basic income is generated by specific concerns about growing economic inequality and the changing nature of work. As evidence of this inequality, Oxfam has noted the increasing concentration of wealth in the hands of a small group of billionaires. In 2018, 26 people owned the same amount of wealth as the 3.8 billion people who comprise the poorest half of the world's population - in 2017, this figure was 43 people. ${ }^{45}$ Few countries seem willing or able to tax the global companies that generate this wealth. While inequality is growing the rate of reduction of extreme poverty had slowed by half since 2013 according to the World Bank. ${ }^{46}$ The Bank is now projecting that the economic impacts of COVID-19 will result in 'the first increase in global extreme poverty since 1998, effectively wiping out progress made since 2017'. ${ }^{47}$ Inequality has severe consequences for political and economic stability, health and the environment. ${ }^{48}$

This inequality manifests in many parts of the world in underemployment and salary stagnation. Precarious labour conditions are a reality for millions within the increasingly global labour market. There are fears about the loss of jobs in what has been labelled the 'Fourth Industrial Revolution' which entails changes in scale and scope that cannot yet be

\footnotetext{
"Michael W Howard, Jorge Pinto and Ulrich Schachtschneider, 'Ecological Effects of Basic Income' in Malcolm Torry (ed), The Palgrave International Handbook of Basic Income (Palgrave Macmillan 2019); Greg Marston, 'Greening the Australian Welfare State: Can Basic Income Play a Role?’ in Jennifer Mays, Greg Marston and John Tomlinson (eds) Basic Income in Australia and New Zealand: Perspectives From the Neoliberal Frontier (Palgrave Macmillan 2016) 157-77.

${ }^{45}$ Max Lawson and others, 'Public Good or Private Wealth?' (2019) Oxfam Briefing Paper 12 <https://indepth.oxfam.org.uk/public-good-private-wealth/> accessed 1 September 2020.

${ }^{46}$ World Bank, Poverty and Shared Prosperity 2018: Piecing Together the Poverty Puzzle (World Bank Publications 2018).

${ }^{47}$ World Bank Brief, 'Projected Poverty Impacts of COVID-19' (2020) <https://www.worldbank.org/en/topic/poverty/brief/projected-poverty-impacts-of-COVID19> accessed 1 September 2020.

${ }^{48}$ Richard Wilkinson and Kate Pickett, The Spirit Level: Why More Equal Societies Almost Always Do Better (Allen Lane 2009); Branko Milanovic, The Haves and the HaveNots: A Brief and Idiosyncratic History of Global Inequality (Basic Books 2012).
} 
predicted, including via robotics, artificial intelligence, biotechnology, the 'internet of things' and quantum computing. ${ }^{49}$ These technologies are likely to reduce employment in many areas with some uncertainty about whether new forms of income generating work will arise to replace the old jobs or whether many people will become unemployed or underemployed leading to even greater inequality and insecurity. It is these concerns about both a crisis in work and the related challenges of inequality that have led to calls for a basic income from a range of quarters. A basic income is being seen variously as 'venture capital for the poor', a response to poverty and austerity, and as a means of freeing people to work as they choose rather than remain in meaningless, unsatisfying 'bullshit jobs'.

The interest in basic income has seen the emergence of trials aimed at testing the impacts of such a policy. A two-year trial in Finland (2017-19) gave 2,000 unemployed people $€ 560$ per month. ${ }^{51}$ Trials were begun and then suspended in Ontario, Canada around the same time, while Scotland is currently considering trials in certain local authorities. Trials have also been proposed or funded by non-government bodies: A trial in the Indian state of Madhya Pradesh was funded by UNICEF; $;^{52}$ a tech company, Y Combinator, has planned a trial in Oakland, California; and a charity funded a trial in Kenya. The difficulty with trials is that a small group is selected rather than testing a whole of population program. This makes it challenging to evaluate the likely economic, social and political impacts on a country. In addition, the success of trials depends on what they are designed to test which is complicated by the range of sometimes conflicting claims proposed by different basic income supporters. Nevertheless, it is possible to learn something from trials such as their impact at the household level and on people's behaviours and choices, and pilots may have inherent value for the recipients. Trials also appear to be promoted politically in efforts to advance the idea of a basic income. Standing notes however, that core philosophical justifications of a basic income - 'social justice, freedom and economic security' cannot be tested. He argues that 'if basic income is considered a right, asking if it 'works' makes no sense,

\footnotetext{
${ }^{19}$ Klaus Schwab, The Fourth Industrial Revolution (Penguin 2017).

${ }^{50}$ See Albert Wenger, 'Basic Income: An Introduction' (72 ${ }^{\text {nd }}$ Annual NYU Labor $\begin{array}{lllll}\text { Conference, } & \text { New } & \text { York, } & 13 & \text { June }\end{array}$ <https://continuations.com/post/185978039865/universal-basic-income-an-introduction> accessed 1 September 2020; Bregman (n 2).

${ }^{51}$ Luke Martinelli, 'Basic Income: World's First National Experiment in Finland Shows Only Modest Benefits' (The Conversation, 22 February 2019) <https://theconversation.com/basic-income-worlds-first-national-experiment-in-finlandshows-only-modest-benefits-111391> accessed 1 September 2020.

${ }^{52}$ Sarath Davala and others, Basic Income - A Transformative Policy for India (Bloomsbury 2015).
} 
any more than the abolition of slavery'. ${ }^{53}$ The article now turns to this idea of basic income as a human right.

\section{Basic Income as a Human Rights Issue}

A number of human rights are implicated in considerations of a basic income including the right to an adequate standard of living ${ }^{54}$ and the right to social security. ${ }^{5,5}$ Underlying values of freedom, dignity and equality that shape the human rights project also animate the specific rights that might apply to a basic income. The UN Special Rapporteur on extreme poverty and human rights, Philip Alston's report argued that alongside the many motivations for a basic income, it should be endorsed because of its capacity to advance fairness and social justice, central to the human rights project. ${ }^{56} \mathrm{He}$ stressed the need to bring together the call for Social Protection Floors in the ILO's Social Protection Floors Recommendation (No. 202) and in Goal 1 of the Sustainable Development Goals with the discussion of a basic income. ${ }^{57}$ While accepting that there are differences between these ideas, he urged proponents of both to focus on their synergies. ${ }^{58}$

Alston's report has generated responses from within the UN system. The ILO, in its World Social Protection Report, noted that the concept of a social protection floor 'guarantees a basic level of income security throughout the life cycle, which should allow life in dignity'. ${ }^{59}$ However, the report suggests that this can be achieved in different ways - via a basic income or through other means such as '(other) universal benefit schemes, social insurance schemes, social assistance schemes, negative income tax, public employment or employment support schemes, in cash or in kind'. ${ }^{60}$ It noted that a combination of measures is needed including contributory and tax financed social security to build comprehensive social security systems. ${ }^{61}$ Paul Ladd, the director of the UN Research Institute for Social Development, argued that a basic income could enhance human rights but that alone it is insufficient to overcome inequality and employment

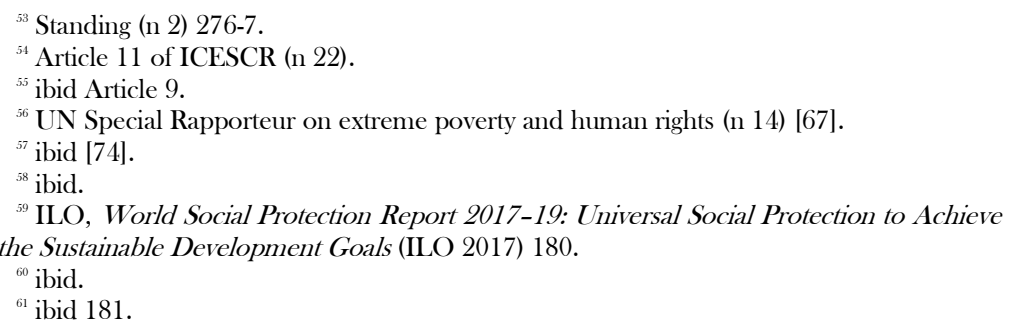




\section{"Basic Income"}

disruption. ${ }^{62}$ It would need to sit alongside other social and economic rights such as health and housing as well as creative tax mechanisms to address wealth inequalities. An ILO working paper examining basic income proposals stressed that the provision of basic income security to all was central to the ILO's mandate and the concept of a social protection floor. It agreed with Alston on the need to bring the basic income and social protection floor discussions together and suggested that ' $[\mathrm{A}]$ rguably, a UBI would be the most radical form of the income component of a social protection floor ${ }^{63}$ On this basis a basic income would go a long way towards realising social rights as minimums although it would not necessarily address economic inequality at the level of wealth concentration in the hands of the few. ${ }^{64}$ The ILO report found that different basic income proposals must be assessed against ILO standards as some have the 'potential to advance equity and social justice, while other proposals may result in a net welfare loss'.

The arguments about a basic income being only one possible way of ensuring social protection consistent with human rights is supported by interpretation of the language of ICESCR. Article 9 provides a 'right of everyone to social security, including social insurance'. While this sparse language leaves the task of interpretation of the right to the treaty committee, it seems likely from the wording that social security includes both social assistance and social insurance. The Committee on Economic, Social and Cultural Rights has noted, in relation to coverage, that the right requires that: ${ }^{66}$

\section{All persons should be covered by the social security system, especially individuals belonging to the most disadvantaged and marginalized groups, without discrimination on any of the grounds prohibited under article 2, paragraph 2, of the Covenant. In order to ensure universal coverage, non-contributory schemes will be necessary.}

Thus, although the language of 'everyone' requires universal reach of the right it does not preclude different forms of social security chosen

\footnotetext{
${ }^{62}$ Paul Ladd, 'Universal Basic Income - Necessary but not Sufficient?' (Social Protection \& Human Rights, 13 June 2017) <http://socialprotectionhumanrights.org/expertcom/universal-basic-income-necessary-not-sufficient/> accessed 1 September 2020 .

${ }^{63}$ Ortiz and others (n 18) 5.

${ }^{64}$ On the capacity of social rights to address economic inequality see Moyn (n 33).

${ }^{65}$ ibid 29.

${ }^{66}$ CESCR, 'General Comment No 19' (n 23) [23].
} 
within a given country. It would be difficult to argue that a basic income is the required form of the right if a combination of social insurance and social assistance ensures comprehensive social protection in a given society. This does not of course prevent a country from deciding to provide a basic income alongside existing social security measures (both insurance and assistance). While some proponents of a basic income see it as a replacement of existing social security measures in the interests of simplifying systems and saving costs, many supporters of a basic income imagine it being installed alongside other social protection measures. A basic income, were it the only form of social protection, would have to be of sufficient size to comprehensively cover everyone in society.

Similarly, the right to an adequate standard of living in Article 11 of ICESCR does not specify a particular form of realisation. The right includes 'adequate food, clothing and housing' and 'the continuous improvement of living conditions'. It seems clear that such living conditions could be provided and improved in a range of ways that would achieve the intention of the right, with a basic income being just one of these.

The right to work is also relevant to discussion of a basic income. Article 6 of ICESCR includes 'the right of everyone to the opportunity to gain his living by work which he freely chooses or accepts' ${ }^{67}$ Arguably a basic income provides people with the opportunities to make unconstrained choices about the work they do whether or not it is remunerated if we understand work in a broader, non-commodified sense. A basic income may also provide the income security to allow people to look for work or different/better work. But the right to work can be fulfilled in other ways such as through jobs guarantees and public works programs - again a basic income is not the only possibility.

Any basic income proposals should be evaluated in terms of their capacity to meet people's human rights. In addition to the ILO standards, the body of commentary on the right to social security and related rights is evolving in national, regional and international law and is important in assessing basic income proposals. ${ }^{68}$ For example, as noted above, a basic income that removes other payments leaving certain groups more vulnerable may violate the principle of non-retrogression of the right to social security; ${ }^{69}$ a basic income paid at a level below that which a person can live on with dignity may violate the adequacy dimension of the right. ${ }^{70}$

\footnotetext{
${ }^{67}$ Article 6 of ICESCR (n 22).

${ }^{68}$ See Eibe Reidel (ed), Social Security as a Human Right (Springer 2007); Jef Van Langendonck (ed), The Right to Social Security (Intersentia 2007); Goldblatt, Developing the Right to Social Security (n 20).

${ }^{69}$ CESCR, 'General Comment No 19' (n 23) [42].

${ }^{70}$ ibid [22].
} 


\section{"Basic Income”}

A rights framework may also prove important in the design, implementation and conclusion of basic income trials. ${ }^{71}$

Basic income has also arisen in UN human rights treaty body recommendations in response to state parties' reports. The Committee on Economic, Social and Cultural Rights recommended that a basic income be considered in South Africa, ${ }^{72}$ Namibia, ${ }^{73}$ and Albania. ${ }^{74}$ Haiti has recommended, through the Universal Periodic Review, that a variety of countries 'Establish an inclusive dialogue on a universal basic income as a tool to change the current social security system, in consultation with all stakeholders' (or other versions of this sentiment). ${ }^{75}$ At the national level consideration of a basic income has been framed in terms of constitutional rights. In 2002, a government appointed Committee of Inquiry into a Comprehensive System of Social Security for South Africa recommended the introduction of a basic income. While the recommendation was not adopted it has been argued that a basic income would give effect to the right to social security contained in South Africa's constitution. ${ }^{76}$

Before exploring the gender dimensions of human rights considerations of basic income, the article sets out some of the feminist debates regarding basic income.

\section{Feminist Debates on a Basic Income}

Economic inequality has profound gender dimensions. As Oxfam's 2020 report notes, the global 'economic system is built on sexism'. ${ }^{77}$ The major burden of caring in all societies falls on women who largely provide this work without pay. This work impacts on women's access to paid work and

\footnotetext{
${ }^{71}$ See, for example on this social, economic and cultural rights framework, the statement by the CESCR, 'The Pledge to "Leave No One Behind": The International Covenant on Economic, Social and Cultural Rights and the 2030 Agenda for Sustainable Development'(2019) E/C.12/2019/1.

${ }^{72}$ CESCR, 'Concluding Observations: South Africa' (2018) E/C.12/ZAF/CO/1 [48].

${ }^{73}$ CESCR, 'Concluding Observations: Namibia' (2016) E/C.12/NAM/CO/1 [25].

${ }^{77}$ CESCR, 'Concluding Observations: Albania' (2013) E/C.12/ALB/CO/2-3 [21].

${ }^{75}$ Working Group on the Universal Periodic Review, 'Uruguay' (2019) A/HRC/41/8 [118.88]. Other countries where similar recommendations have been made include Guatemala, The Netherlands, South Africa, India, United Kingdom of Great Britain and Northern Ireland, Timor-Leste, Iceland, Ireland, and the Seychelles.

${ }^{76}$ Sandra Liebenberg, 'Universal access to social security rights: Can a basic income grant meet the challenge?' (2002) 3(2) ESR Review 8; June Sinclair, 'Poverty: Giving Meaning to the Right to Social Assistance' (2012) 23(2) Stellenbosch Law Review 191.

${ }^{77}$ Clare Coffey and others, 'Time to Care: Unpaid and Underpaid Care work and the Global Inequality Crisis' (2020) Oxfam Briefing Paper, January 2020, 20 <https://www.oxfam.org/en/research/time-care> accessed 1 September 2020.
} 
other economic opportunities and contributes to the gender pay gap found across the world. ${ }^{78}$ Oxfam estimates the value of women's unpaid care work at $\$ 10.8$ trillion annually which is three times the size of the world's tech industry. ${ }^{79}$ Sexism is a key driver of wealth inequality and also impacts directly on women's income. Women are likely to fill the most precarious and poorest paid positions in society and to earn significantly lower wages than men. ${ }^{80}$ Technological and other drivers of un- and under employment are thus likely to impact harshly on women workers. At the same time, austerity policies and service cuts disadvantage women and girls more than men as the burden shifts from the state to the household. ${ }^{81}$ Feminists have long recognised that the capitalist system profits from the unpaid labour of women through the social and biological reproduction of society. ${ }^{82}$ It is this fault line, premised on women's biological difference but deeply embedded in social structures, that hampers women's progression in the job market and economy.

The challenging global context and long-standing impact of sexism have important implications for the forms of social protection that can both mitigate the effects of gender inequality and contribute to its eradication. There is an emerging acknowledgment of the need for such measures. The UN's Sustainable Development Goals, one of which is aimed at achieving gender equality (Goal 5) targets the recognition and valuing of 'unpaid care and domestic work through the provision of public services, infrastructure and social protection policies and the promotion of shared responsibility within the household and the family as nationally appropriate. ${ }^{93}$ Which social protection policies will best address gender divisions of work and care alongside the broader challenges of poverty and inequality facing the world is a key question. Basic income, posited by many as a solution to the challenges of inequality and work, has been of interest to feminists grappling with the sexual division of labour in the home and workplace and its dire consequences for women.

\footnotetext{
${ }^{78}$ World Bank, 'World Bank Group Gender Strategy (FY16-23): Gender Equality, Poverty Reduction and Inclusive Growth' (2015) World Bank Working Paper No 102114 <http://documents.worldbank.org/curated/en/820851467992505410/World-Bank-Groupgender-strategy-FY16-23-gender-equality-poverty-reduction-and-inclusive-growth> accessed 1 September 2020.

${ }^{79}$ Coffey and others (n 77) 20.

${ }^{80}$ ibid 25.

${ }^{81}$ ibid 26.

${ }^{82}$ Antonella Picchio, Social Reproduction: The Political Economy of the Labour Market (CUP 1992); Marilyn Waring, If Women Counted: A New Feminist Economics (Harper Collins Publishers 1988).

${ }^{83}$ Target 5.4, 'Transforming our World: the 2030 Agenda for Sustainable Development' <https://sustainabledevelopment.un.org/post2015/transformingourworld> accessed 1 September 2020 .
} 


\section{"Basic Income”}

Proponents of a basic income suggest it has value for women in delinking social security from work given the disadvantages faced by women in the job market. ${ }^{84}$ Work interruptions to have children and fulfil care roles result in shorter careers, lower wages and smaller accumulation of retirement savings for women, making them more dependent on men and vulnerable in old age. A basic income could enhance women's freedom to make life choices, including allowing them to live independently of men at different stages of their lives. ${ }^{85}$ This is an important consideration given the economic vulnerability facing single mothers and single older women in many countries, worsened by austerity and economic crisis. A basic income would enable women to leave violent relationships if they were assured of income for themselves and their children. ${ }^{86}$

A basic income has also been supported as a necessary means of enhancing women's democratic citizenship. ${ }^{87}$ By focusing on reciprocity across the society, the debate about a basic income can open up conversations about reciprocity within the household. ${ }^{88} \mathrm{~A}$ basic income recognises unpaid and affiliative work as socially valuable and thus has the potential to change understandings of social citizenship. ${ }^{89}$ The shift from work to citizenship as the source of income thus increases the possibility of transformed gender relations. Nancy Fraser's transformative model of citizenship, 'the universal care-giver model', sees all members of society participating in paid work and unpaid care with social institutions restructured to support this..$^{90} \mathrm{~A}$ basic income, or some variant of it, might enable this change leading to a more equal division of care and work. ${ }^{91} \mathrm{Cox}$ suggests reframing basic income as a 'universal social dividend' since this would 'redefine such income as produced by valuing wide-ranging unpaid

\footnotetext{
${ }^{84}$ Anne L Alstott, 'A Basic Income for All - Good for Women' (Boston Review, 1 October $2000)$ <http://bostonreview.net/archives/BR25.5/alstott.htm> accessed 1 September 2020.

${ }^{85}$ Ann Withorn, 'Women and Basic Income in the US: Is One Man's Ceiling Another Woman's Floor?' (1993) 4 Journal of Progressive Human Services 29; Petra Bueskens, 'Poverty-traps and Pay-gaps: Why (Single) Mothers Need Basic Income' in Tim Hollo (ed), Views of a Universal Basic Income: Perspectives from across Australia (The Green Institute 2017).

${ }^{86}$ Tony Fitzpatrick, Freedom and Security: An Introduction to the Basic Income Debate (Macmillan 1999).

${ }^{87}$ Carole Pateman, 'Democratizing Citizenship: Some Advantages of a Basic Income' (2004) 32 Politics \& Society 89.

${ }^{88}$ ibid.

${ }^{89}$ Ailsa McKay, The Future of Social Security Policy: Women, Work and a Citizens'Basic Income (Routledge 2005).

${ }^{90}$ Nancy Fraser, 'After the Family Wage: A Post-Industrial Thought Experiment' in Nancy Fraser (ed), Justice Interruptus: Critical reflections on the 'Post-Socialist' Condition (Routledge 1997).

${ }^{91}$ Miller and others (n 19) 136; Fitzpatrick (n 86).
} 
contributions to collective social well-being and counter some of the materialist gender inequities of economic models'. ${ }^{92}$ The challenge to decommodify human activity so that 'affiliative' work is valued must be built into policies aimed at achieving gender equality. ${ }^{93}$ Pateman points out that a feminist lens reorients the basic income debate away from economic questions to ones related to democratisation since it focuses on issues of citizenship and institutions including the workplace and marriage. ${ }^{94}$ While the debate is often concerned with 'free-riding', those who choose not to work while depending on the income of others, a feminist understanding shifts the examination of free-riding to men who continue to expect women to perform the bulk of social reproductive work within their households even when both partners are in paid employment. The idea of a basic income paid to individual women as a citizenship entitlement rather than to the household where it may not be shared equally is important for feminism and democratisation..$^{95}$

Detractors have argued that a basic income does less to challenge unequal responsibilities between men and women for social reproduction than other more direct mechanisms might achieve in tackling the gendered structure of paid and unpaid work. ${ }^{96} \mathrm{~A}$ basic income is seen as less enabling of women, particularly lone mothers, than a comprehensive welfare state, ${ }^{97}$ and might even worsen their position by '(re)privatizing' care in supporting them to stay outside of the labour market. ${ }^{98}$ Thus, a basic income may support the maintenance of the gender division of labour. By allowing women the choice to work in the home it could reinforce existing assumptions about unpaid work in the home being women's work while reducing opportunities for some women to access the labour market, furthering their disadvantage in relation to future wage potential and reducing their savings. Based on current social attitudes, there is nothing to suggest that more men will take advantage of the opportunity to do more unpaid work in the home, even if they choose to do less paid work in the market. Some feminists have been more tentative in their responses to a

\footnotetext{
${ }^{92}$ Eva Cox, 'Feminist Perspectives on Basic Income' in Elise Klein and others (eds), Implementing a Basic Income in Australia, Exploring the Basic Income Guarantee (Springer 2019) 81. Also see Eva Cox, 'Why a Universal Basic Income Can Address Historic, Gender and Material Inequities' in Tim Hollo (ed), Can Less Work Be More Fair? A discussion Paper on Universal Basic Income and Shorter Working Week (The Green Institute 2016).

${ }_{93}^{93}$ McKay (n 89) 203.

${ }^{94}$ Pateman (n 87).

${ }_{95} \mathrm{ibid}$.

${ }^{96}$ Ann Orloff 'Comment on Ann Withorn: Is One Man's Ceiling Another Woman's Floor? Women and BIG' ( $3^{\text {rd }}$ International Conference on Basic Income, Florence, 1990).

${ }^{97}$ Barbara R Bergmann, 'Basic Income Grants or the Welfare State: Which Better Promotes Gender Equality?' (2008) 3(3) Basic Income Studies 1.

${ }^{98}$ Anca Gheaus, 'Basic Income, Gender Justice and the Costs of Gender-Symmetrical Lifestyles' (2008) 3(3) Basic Income Studies 8.
} 
basic income, with concerns that further information on the size of a basic income and empirical studies are needed. ${ }^{9}$

Some proponents suggest that universal childcare must accompany a basic income if it is to succeed in unseating sexual divisions of work and care. However, the cost implications of providing both might be economically and politically unfeasible. Young, writing in the Canadian context, has supported the idea of a basic income alongside other essential features of a welfare state that improve the position of women. ${ }^{100}$ She argues that a focus on basic income as the key policy option to redistribute resources risks failing to focus on the problems of the market in terms of its 'provision of services and its treatment of workers'. ${ }^{101}$ The focus of a basic income on the individual can foreclose a focus on structures that create and maintain inequality. Aside from these conceptual concerns with a basic income there are many practical concerns about the size and shape of a basic income and the possibility that achieving it results in policy losses for women or groups of women currently benefiting from more targeted measures. A final concern with the basic income debate is raised by feminists from the Global South who question whether a small payment will be sufficient to address extreme poverty and inequality; and whether women will be able to control this income at the household level or be in any way better placed to resist violence. ${ }^{102}$

The article now moves from these feminist and human rights perspectives on a basic income to explore what human rights directed at advancing gender equality might bring to a consideration of a basic income.

\section{Basic Income, Gender and Human Rights}

A central question emerging from the feminist debates is whether a basic income would address the economic and social inequalities that underlie the inadequate realisation of women's human rights and shift gender roles and responsibilities. As noted above, a basic income has implications for a range of rights including the right to an adequate livelihood, the right to

\footnotetext{
${ }^{99}$ Ingrid Robeyns, 'Introduction: Revisiting the Feminism and Basic Income Debate' (2008) 3(3) Basic Income Studies.

${ }^{100}$ Margot Young, 'Women's Work and a Guaranteed Income' in Shelley AM Gavigan and Dorothy E Chunn (eds), The Legal Tender of Gender: Law, Welfare and the Regulation of Women's Poverty (Hart 2010).

${ }^{101}$ ibid 269.

${ }^{102}$ Shireen Hassim, 'Gender Equality and Developmental Social Welfare in South Africa' in Shireen Hassim and Shahra Razavi (eds) Gender and Social Policy in a Global Context: Uncovering the Gendered Structure of 'the Social' (Springer 2006) 109-129.
} 
work and the right to social security. There has been minimal attention to the debate on basic income as it relates to gender and human rights. An article by Patricia Schulz, a former member of the UN Committee on the Elimination of Discrimination Against Women, endorsing a basic income from a gender rights perspective, is one of the few such rights-based arguments. ${ }^{103}$ Shulz suggested that a basic income is the logical way of linking economic security to other human rights including gender equality based on various rights within key human rights instruments (ICESCR, Convention on the Elimination of All Forms of Discrimination Against Women ${ }^{104}$ and the Universal Declaration of Human Rights ${ }^{105}$ ) and the commitments emerging from the ILO Social Protection Floor Recommendation 202 and the Sustainable Development Goals. ${ }^{106}$

As discussed above, social protection rights informed by gender are important in assessing the idea of a basic income and may also be helpful in evaluating the specifics of different basic income policy proposals. The ILO working paper noted that immediate benefits of a basic income for women through increased provision of income may lead to longer term disadvantages if previously funded government services and benefits are privatised. It pointed out that:

Regressive UBI budget-neutral proposals that suggest the
replacement of public social insurance systems by a
modest UBI, promoting individual savings and private
insurance for those who can afford it, are not in line with
ILO standards and would have negative impacts on
women, as women tend to have shorter careers, lower
earnings and lesser savings. ${ }^{107}$

It suggested that gender-sensitive employment and care policies would have to accompany basic income policies. ILO standards alongside broader human rights requirements are therefore critical in evaluating basic income within the context of a country's overall approach to social protection and other dimensions of policy and provision that impact on gender equality.

A basic income in a society where women have more limited access to paid work and social security than men might advance equality and address gender disadvantage by empowering women financially. Since women

\footnotetext{
${ }^{103}$ Patricia Schulz, 'Universal Basic Income in a Feminist Perspective and Gender Analysis' (2017) 17 Global Social Policy 89.

${ }^{104}$ (adopted 18 December 1979, entry into force 3 September 1981) 12249 UNTS 13.

${ }^{10.5}$ (adopted 10 December 1948 UN General Assembly Resolution 217A(III)) 48)

${ }^{106}$ ibid 91.

${ }^{107}$ Ortiz and others (n 18) 28.
} 


\section{"Basic Income”}

tend to be disproportionately represented among the poor, this is a compelling equality argument for a basic income. However, the universality of a basic income, while attractive in principle, is itself indiscriminate in treating all people in the society alike. It could therefore be seen as a formal equality measure, inadequate in addressing the structural disadvantages facing women. Young observes that the (neo-) liberal goods of economic liberty and formal equality resound strongly for women - but they are loaded freight and also function to justify much of modern economic and social relations that are deeply oppressive and unequal for women'. ${ }^{108}$ As a formal equality measure designed by its universal nature to give everyone an equal sum, those who start off more disadvantaged may not see their position significantly altered, and existing hierarchies of power and privilege may not be shifted.

A substantive gender equality approach might be better served by designing social protection that is directed at the most vulnerable in society. A basic income could achieve this if accompanied by additional payments for groups such as sole parents, to remedy their disadvantages. Much hinges on the particular design of a basic income and whether it sits on top of, rather than replaces, necessary social assistance for groups in need of this support. ${ }^{109}$ Its gender equality impacts will therefore depend on the way in which the broader social protection system acknowledges and responds to gender disadvantage in line with the human rights framework. A basic income policy that replaces existing social protection measures must not be regressive in removing benefits aimed at advancing women's economic security. As noted, non-retrogression requires the meaningful participation of affected groups to consider proposed changes to existing policies that might tamper with their rights.

Basic income as a form of universal and unconditional social assistance has significant appeal to many groups of women currently frustrated by punitive and patchy systems. ${ }^{110}$ It offers unencumbered access to income for unpaid carers and precarious workers, groups that are women dominated and face challenges under many social security systems. These groups may struggle to meet activation requirements such as job seeking while balancing caring obligations; and may also be burdened with responsibilities that are sometimes attached via conditions to cash transfers. ${ }^{111}$ These arguments suggest that in some contexts a basic income

\footnotetext{
${ }^{108}$ Gheaus (n 98) 271.

${ }^{109}$ Some proponents stress that a minimum income to all must be accompanied by supplementary payments and other benefits to disadvantaged groups, see Standing (n 2).

${ }^{110}$ See Bueskens (n 85).

${ }^{111}$ Maxine Molyneux, 'Mothers at the Service of the New Poverty Agenda: Progresa/Oportunidades, Mexico's Conditional Transfer Programme' (2006) 40 Social Policy \& Administration 425.
} 
will enhance equality and rights to social protection by bringing poor women and carers into the social protection fold without additional demands being placed on them. ${ }^{112}$ But this alone will not undo the structural disadvantage that these groups face and will not necessarily be transformative in altering the gendered responsibilities for care; nor will it necessarily remove all the barriers to, and within, the labour market facing women and carers.

This suggests that a substantive gender equality approach could endorse a basic income if it offered more to women in a given society than already existed. But it would also require further social policy measures to redress the sexual division of labour at work and home. These changes are unlikely to flow automatically from a basic income where structural inequalities along gender lines are embedded in society. Other measures will be needed, whether through state provision, market regulation or norm realignments or combinations of these to spread caring in more gender equal ways. A basic income would need to sit alongside state support to realise other interdependent human rights including health care, housing, social services and worker rights, themselves developed in accordance with substantive gender equality.

As noted, a substantive equality approach also requires an intersectional understanding of inequality. If the introduction of a basic income sees certain social assistance reduced or removed this might lead to lower benefits for some groups such as older women. Miller and others, in examining the history of demands for basic income type policies, stress that class and ethnic differences should inform assessments of the gender impacts of a basic income. They point out that:

Where middle-class and professional women see a danger in Basic Income's support for, and implicit endorsement of, traditionally female roles in providing unpaid care, poor women and welfare claimants see the emancipatory promise of allowing them to decide for themselves, on a foundation of economic security, whether and how to combine the multiple roles that women have always performed, rather than being forced to choose dependence on either a breadwinning spouse or on a lowpaying job. ${ }^{113}$

\footnotetext{
${ }^{112}$ For a discussion of the human rights and gender dimensions of conditional social security see Fredman (n 20).

${ }^{113}$ Miller and others (n 18) 145.
} 
This intersectional complexity means that a gender equality evaluation of basic income must be nuanced and thoroughly contextual. ${ }^{114}$ This extends to thinking about the types of work women do and which of these are acknowledged and supported by basic income. A basic income might be endorsed because it supports care and other unpaid work often performed by women. While this could provide important recognition, as many feminist critics have warned, it may do little to encourage men to take on this work and may even worsen the unequal share carried by women. Basic income might also be used to justify informal and precarious work which is often women dominated on the basis that the society provides for this group's social protection in the absence of labour/marketbased protection. A basic income would have to consider the needs of vulnerable women such as migrants and refugees in ensuring an accessible policy consistent with human rights since some basic income proposals are restricted to citizens. It would also have to recognise contingencies across the life-course to ensure that the needs of older women, women with disabilities, pregnant women, and so on, are accommodated in policy proposals.

Turning to the issue of adequacy, an essential element of the right to social security and directly linked to the realisation of other rights to livelihood, health care and social protection, a basic income payment would have to be of an adequate size to provide enough to enable people to make choices about their lives and give them access to the full range of human rights to which they are entitled. It would have to meet both individual and family needs, regardless of the nature of the family, of particular importance in the case of sole parent families. A minimalist basic income that did not provide an adequate livelihood would violate human rights and would deny women the means to overcome their structural disadvantage. It would also do little to address their unequal status or subvert gendered patterns of work and care. A basic income would need to transcend minimalist logics and be redistributive to contribute to far-reaching social and economic equality. In order to be substantively gender equal it would have to be designed with women in mind (and with their involvement) to ensure that it is appropriate, adequate and complemented by other social protection measures that contribute to transforming gender relations in society. Of course, affordability is frequently raised as a concern in basic income debates, particularly in the Global South. Human rights underpinned by substantive equality would expect these social protection challenges to be addressed within the context of tax, debt and other restructuring measures at local and global

\footnotetext{
${ }^{114}$ An intersectional lens may also aid in assessing the possible impact of a basic income on other forms of vulnerability.
} 
levels, including by way of international cooperation. To be transformative a basic income would require far-reaching enabling and complementary measures to realise human rights. On its own a basic income would not necessarily overcome economic inequality. For it to contribute to transformative, redistributive outcomes, it would have to be accompanied by other forms of economic restructuring. Similarly, if substantive gender equality is to be achieved, an adequate basic income would not on its own be enough to unravel patriarchal relations.

\section{Human Rights, Basic Income and the Feminist Project}

As discussed above, the call for a basic income comes from conservatives and progressives alike although their motivations for proposing it and their hopes for its impact differ widely. From the perspective of a left agenda, the call for a basic income offers challenges to the existing understanding of work in the context of our current capitalist system. As Kathi Weeks has expressed: ${ }^{115}$

The collective political activity of demanding a basic income is as interesting to me as the demand itself. A demand is not just a thing, but something that must be explained, justified, argued for and debated. The practice of demanding is itself productive of critical awareness and new political desires. Demanding a basic income, as I see it, is also a process of making the problems with the wage system of income allocation visible, articulating a critical vocabulary that can help us to understand these problems, opening up a path that might eventually lead us to demand even more changes, and challenging us to imagine a world wherein we had more choices about waged work, nonwork, and their relationship to the rest of our lives. By this account, we would judge the success or failure of a movement for basic income not only in terms of whether the policy is implemented, but also in terms of the collective power, organizational forms, critical

\footnotetext{
${ }^{115}$ Katie Cruz, 'A Feminist Case for Basic Income: An Interview with Kathi Weeks' (Critical Legal Thinking, 22 August 2016) <http:/criticallegalthinking.com/2016/08/22/feminist-casebasic-income-interview-kathi-weeks/> accessed 1 September 2020.
} 


\section{"Basic Income"}

consciousness, and new demands that the process of demanding it manages to generate.

The basic income debate is both a process of claim-making and a means of exposing what is wrong with our existing systems. It is also an opportunity to consider new ideas for social and economic organisation. This has obvious appeal to feminists since the project of feminism is by its nature both critical of what we have, political in demanding change, and utopian in visualising a different way of structuring gender in society. ${ }^{116}$ This aligns well with aspects of the human rights project, an attempt to progressively realise a fairer world. As Philip Alston puts it: ${ }^{117}$

... the utopian vision may also provide the much-needed impetus to rethink the optimal shape of social protection explicitly designed to achieve universal realization of the human right to an adequate standard of living in the twenty-first century.

Combining feminist and human rights arguments has the potential to offer a new angle into the basic income debate. A focus on a substantive, redistributive equality approach challenges discourses of minimalism that arise in discussion of a basic income. It also challenges the human rights discussion of a basic income to ensure that gender and equality are fully considered and built into understandings of a rights-compliant basic income proposal. Bringing rights-based arguments into the feminist debate encourages a careful consideration of the evolving framework of guidance on the interpretation of rights (particularly social and economic rights and non-discrimination/equality); and what this might mean for basic income as a policy choice and its specific formulation. Human rights, including ILO standards, direct attention to the requirements of a just social protection system and workplace which can reinforce feminist arguments for new social policies that extend justice to women and challenge sexual divisions of care and work.

\footnotetext{
${ }^{116}$ Nicola Lacey, 'Feminist Legal Theory and the Rights of Women' in Karen Knop, (ed) Gender and Human Rights (2004) 13.

${ }^{117}$ UN Special Rapporteur on extreme poverty and human rights (n 14) [60].
} 


\section{Conclusion}

This article has examined the intersection between feminist discussion of a basic income, its articulation in human rights terms, and how these strands of the basic income debate come together through use of a gender rights lens. The focus on gender in the basic income debate emphasises social reproduction alongside production in attempting to fundamentally reimagine work and care. The human rights lens draws attention to the compatibility of basic income proposals with universally articulated principles of what is required for socially just societies. Combining these leads to a clearer picture of the type of basic income policy that might address the circumstances of different groups of women while also meeting their needs through other forms of social provision. Whether this combination, or any social policy, is capable of fully shifting gender inequalities, particularly as they relate to unpaid work, remains an open question and an ongoing, multi-layered and complex terrain of struggle. 